\title{
High Rate of Overlapping Question Content Among Commonly Used Patient-Reported Outcome Measurements for Anterior Cruciate Ligament Injury
}

\author{
Hayley L. Jansson, M.D., Nnaoma M. Oji, B.S., Kendall E. Bradley, M.D., \\ C. Benjamin Ma, M.D., Alan L. Zhang, M.D., and Brian T. Feeley, M.D.
}

\begin{abstract}
Purpose: To precisely compare the questions and content between the most commonly cited knee-specific patient-reported outcome measurements (PROs) for anterior cruciate ligament (ACL) injury. Methods: A literature review through Medline from November 1, 2018, to November 1, 2020, was performed to find the most cited knee-specific PROs for assessment of ACL injuries. Each question was then classified as 1) identical, similar, or unique; 2) pertaining to 1 of 6 domains (pain, symptoms, functional activities, occupational activities, sports/recreation, and quality of life). The PROs were then compared to each other to assess question overlap and domain coverage. Results: A total of 133 questions were analyzed from the seven most common PROs: International Knee Documentation Committee (IKDC) form, Knee Injury and Osteoarthritis Outcome Score (KOOS), Lysholm Knee Scoring Scale, Tegner Activity Scale, Marx Scale, Knee Outcome Survey (KOS), and Cincinnati Knee Rating System (CKRS). The total distribution of identical (31.6\%), similar $(31.6 \%)$, and unique $(36.8 \%)$ questions was found to be relatively even. However, this distribution varied within each PRO. KOS and Lysholm had the highest percentages of identical questions (64\% and $62.5 \%$, respectively). KOOS had the highest number of unique questions $(26 / 42,61.9 \%)$, while Tegner held the highest percentage (11/16, 68.8\%). Sports/ recreation was the only domain assessed by all PROs. Conclusion: Nearly two-thirds of questions overlap between the commonly used PROs for ACL injury. Although sports/recreation is assessed by all PROs, each has its own pattern of coverage across this and other domains. Level of Evidence: IV, cross-sectional study.
\end{abstract}

\section{Introduction}

$\mathbf{O}$ utcome measures are valuable instruments in assessment of injury, surgery, and rehabilitation. A standardized manner of evaluation allows

From the Department of Orthopaedic Surgery, University of California-San Francisco, San Francisco, California, U.S.A. (H.L.J., K.E.B., C.B.M., A.L.Z., B.T.F.); and School of Medicine, University of California-San Francisco, San Francisco, California, U.S.A. (N.M.O.).

The authors report the following potential conflicts of interest or sources of funding: C.B.M. is a paid consultant for Conmed, Tornier, and Stryker; has received grants from Zimmer, Aescalap, and Samumed; and has received royalties from Conmed and Slack, outside the submitted work. Full ICMJE author disclosure forms are available for this article online, as supplementary material.

Received April 26, 2021; accepted August 17, 2021.

Address correspondence to Hayley L. Jansson, M.D., Department of Orthoapedic Surgery, University of California-San Francisco, 1500 Owens St., San Francisco, CA 94158,U.S.A.E-mail: hayleyjansson@gmail.com

(C) 2021 THE AUTHORS. Published by Elsevier Inc. on behalf of the Arthroscopy Association of North America. This is an open access article under the CC BY-NC-ND license (http://creativecommons.org/licenses/by-nc-nd/4.0/). 2666-061X/21591

https://doi.org/10.1016/j.asmr.2021.08.006 comparisons between patients, treatments, and studies. These comparisons provide further knowledge and enable clinicians to deliver the highest level of evidence-based medicine. However, studies that examine the same disease process often use different patient-reported outcomes (PROs), making comparisons between studies challenging.

In a 2020 consensus meeting that sought to establish a standardized evaluation of ACL treatment, patientreported outcome (PROs) measures were identified as one of four robust outcome categories; the other three being early adverse events, ACL graft failure/recurrent ligament disruption, and clinical measures of knee function and structure. ${ }^{1}$ A 2015 consensus also recognized PROs as part of the criteria for successful outcome following ACL injury or reconstruction. ${ }^{2}$ PROs allow patients to give a direct report of their health condition. ${ }^{3}$ Previous studies in orthopaedic populations have shown that clinicians, as compared to patients, rate symptoms as less severe and function as better. This discrepancy supports the notion that patient-relevant data should be collected from patients themselves. ${ }^{4}$ 
STEP 1 - Literature search ("anterior cruciate ligament"[title] AND "Patient reported outcome*") from November 1, 2018 to November 1, 2020. Result $=126$ studies

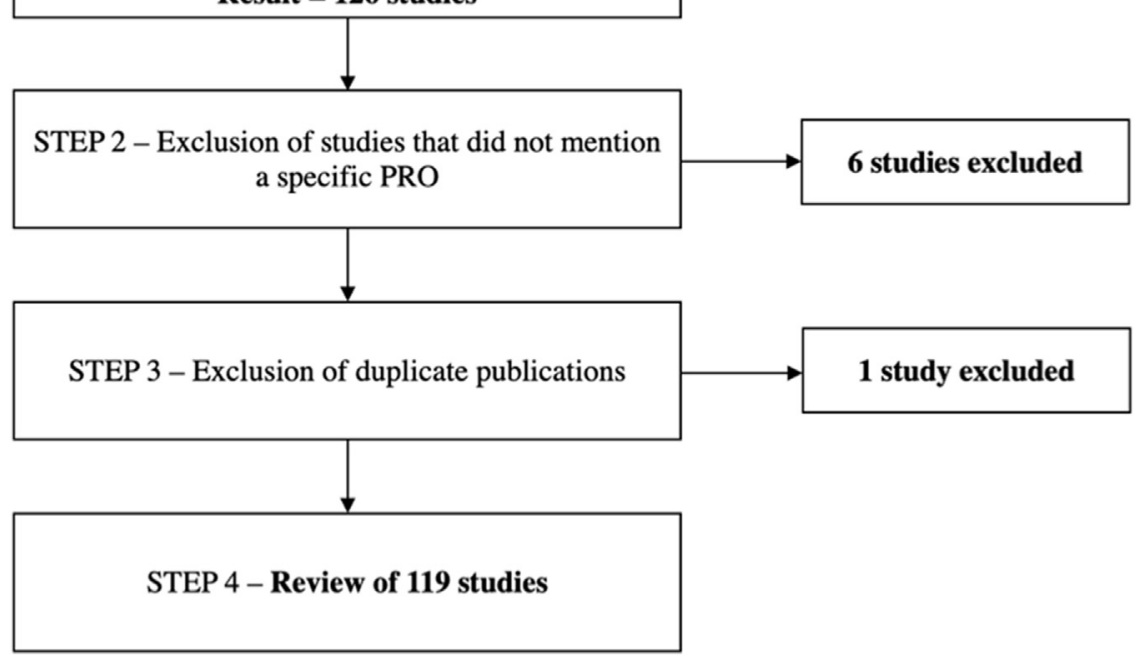

Fig 1. Selection of studies.
Clinicians can use these questionnaires to understand what matters most to patients, such as symptoms with daily activities. ${ }^{5}$

Although earlier studies have assessed the validity and applicability of PROs in evaluating patients with ACL injuries, ${ }^{1,6-8}$ no study has examined exactly how similar these PROs are to each other. Understanding the question content of PROs may allow clinicians and researchers to select the appropriate measurement for a given study or population.

The purpose of this study is to precisely compare the questions and domain coverage between the most commonly cited knee-specific PROs for ACL injury. Our hypothesis is that there is significant overlap (identical or similar questions) between different PROs; however, each PRO may offer a different perspective based on its question composition and focus.

\section{Methods}

A literature review was performed through Medline using "anterior cruciate ligament" [title] AND "patient reported outcome*" from November 1, 2018, to November 1, 2020. This literature search was limited to the preceding 2 years in an effort to capture the most current usage. Duplicate studies and those that did not mention a specific PRO were excluded. From the remaining studies, the most frequently used kneespecific PROs were determined.

Questions from each PRO were then analyzed. Each question was first classified as "identical," "similar," or "unique." A question that was repeated in another PRO was labeled "identical." A question that imprecisely asked about the same activity or symptom was labeled "similar." A question that did not appear in another
PRO was labeled "unique." The classification for each question was agreed upon by all authors. PROs were then compared to each other to determine the amount of overlap (identical and similar questions) and uniqueness.

Next, in reviewing the content of all questions, it was determined that each question could be characterized as pertaining to one of six domains: pain, symptoms, functional activities, sports/recreation, quality of life, and occupational. Again, the domain classification for each question was agreed upon by all authors. Each PRO was then assessed for the degree of coverage across the various domains.

\section{Results}

\section{PRO Questionnaires}

As depicted in Fig 1, literature review of ACL studies involving PROs within the preceding 2 years yielded 126 studies. Six studies did not identify a specific PRO. One study was copublished in more than one journal. Of the remaining 119 studies, the most commonly used knee-specific PROs were the International Knee Documentation Committee (IKDC) form, Knee Injury and Osteoarthritis Outcome Score (KOOS), Lysholm Knee Scoring Scale, Tegner Activity Scale, Marx Scale, Knee Outcome Survey (KOS), and Cincinnati Knee Rating System (CKRS) (Appendix 1).

The most frequently used PRO, found in 83 studies $(69.7 \%)$, was the IKDC form. The IKDC was formed in 1987 by a group of clinicians who felt there was a need for a standardized method to quantify the disability caused by knee ligament injuries and the results of treatment. The IKDC Knee Ligament Standard 
Table 1. The most common knee-specific PROs cited in studies pertaining to ACL injury between November 1, 2018, and November 1, 2020

\begin{tabular}{|c|c|c|c|c|}
\hline & Percent of Studies & Publication Date & Domains & Number of Questions \\
\hline$\overline{\mathrm{IKDC}}$ & $69.7 \%$ & 2001 & $\begin{array}{l}\text { Pain, symptoms, functional activities, } \\
\text { sports/recreation }\end{array}$ & 19 \\
\hline KOOS & $60.5 \%$ & 1998 & $\begin{array}{l}\text { Pain, symptoms, functional activities, } \\
\text { sports/recreation, quality of life }\end{array}$ & 42 \\
\hline Lysholm & $43.7 \%$ & 1982 & Pain, symptoms, functional activities & 8 \\
\hline Tegner & $37.0 \%$ & 1985 & $\begin{array}{l}\text { Functional activities, sports/recreation, } \\
\text { occupational }\end{array}$ & 11 \\
\hline CKRS & $6.7 \%$ & 1983 & $\begin{array}{l}\text { Pain, symptoms, functional activities, } \\
\text { sports/recreation, occupational }\end{array}$ & 19 \\
\hline
\end{tabular}

ACL, anterior cruciate ligament; CKRS, Cincinnati Knee Rating System; IKDC, International Knee Documentation Committee; KOOS, Knee Injury and Osteoarthritis Outcome Score; KOS, Knee Outcome Survey; PROs, patient-reported outcomes.

Evaluation Form was subsequently published in $1993 .{ }^{9}$ In 1997, the American Orthopaedic Society for Sports Medicine (AOSSM) moved to revise the form to broaden its application, including ligament and meniscal injuries, articular cartilage lesions, arthritis, and patellofemoral conditions. The resultant IKDC Subjective Knee Form was published in 2001 and has 19 questions divided in three sections: 1) symptoms, including pain, stiffness, swelling, locking/catching, and giving way; 2) sports and daily activities; and 3) current knee function and knee function prior to knee injury. ${ }^{10}$

The next most common PRO was the KOOS, cited in 72 studies $(60.5 \%)$. The KOOS was published in 1998 as an instrument to assess young and middle-aged patients with ACL injury, meniscus injury, or posttraumatic osteoarthritis. ${ }^{11}$ The creators of KOOS emphasized "patient-relevant outcomes," covering five dimensions: pain, symptoms, activities of daily living, sport and recreation function, and knee-related quality of life. Among the 42 questions is the Western Ontario and MacMaster Universities (WOMAC) Osteoarthritis Index, widely used in the evaluation of patients with hip and knee osteoarthritis. ${ }^{11,12}$

The Lysholm and Tegner forms appeared in 52 (43.7\%) and $44(37 \%)$ studies, respectively. The Lysholm Knee Scoring Scale was originally published in 1982 to evaluate outcomes of knee ligament surgery, particularly symptoms of instability. ${ }^{13}$ The scale was revised in 1985 , at the same time that the Tegner Activity Score was introduced. The Tegner score was intended for use in conjunction with the Lysholm. The Lysholm scale asks about 8 items: limp, support, locking, instability, pain, swelling, stair-climbing, and squatting. To complement this, the Tegner scale consists of a graduated list of sports/ recreation, functional, and occupational activities. The patient selects the option that best describes their activity level at a given time point (i.e., current level, before injury or following surgery).
On the 11-item Tegner Activity Scale, there was occasionally more than one domain asked in a single query. For example, one item combined "sedentary work" (occupational) and "walking on even ground" (functional activities). The decision was made to treat these combined items separately, yielding instead a total of 16 questions for analysis.

The more recently created (2001) Marx scale was used in 13 studies (10.9\%). The goal of the Marx scale is to provide information on a patient's baseline level of activity. ${ }^{14}$ Its authors explained that a patient's activity level must be taken into account when evaluating their outcome. Namely, active patients will have different expectations and demands than patients who are relatively sedentary. The questionnaire was purposely designed with the goal that it could be completed in 1 minute, so as to allow use with other instruments. With this focus, the Marx scale asks about four activities: running, cutting, deceleration, and pivoting. By choosing not to base questions on specific sports, authors are able to compare patients across different activities. The Marx scale distinguishes itself from the Tegner Activity Score by evaluating both the type of activity and the amount of participation time.

Nine studies (7.6\%) employed the KOS. Its 1998 publication explains that the questionnaire was developed from existing instruments, including the CKRS, Lysholm, WOMAC, and IKDC. ${ }^{15}$ The KOS consists of 25 questions within two scales: the Activities of Daily Living Scale (KOS-ADLS) and the Sports Activity Scale (KOS-SAS). The questions address symptoms and functional limitations experienced during activities of daily living and sports activities.

Finally, the CKRS was used in 8 studies $(6.7 \%)$ and consisted of 19 questions. Its first version, published in 1983, focused on knee function in athletic participation. ${ }^{16,17}$ It has been subsequently revised with 
Table 2. Identical Questions

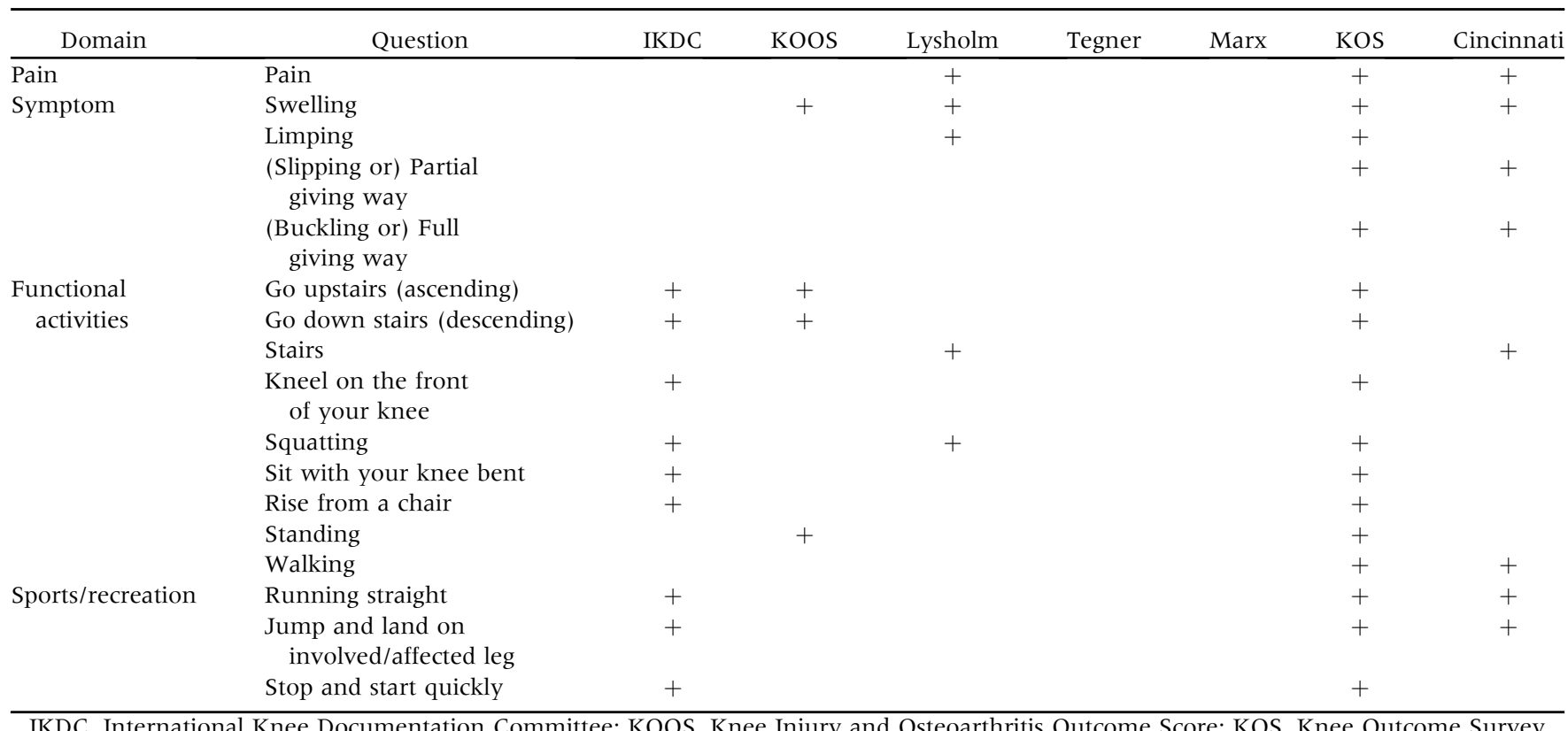

additional scales and modifications for occupational activities, athletic activities, symptoms, and functional limitations with sports and daily activities. ${ }^{18,19}$

\section{PRO Question Analysis of Overlap}

Seven PROs, with a total of 133 questions, were evaluated (Table 1). The KOOS had the highest number of questions (42), with the KOS second (25). The Marx contained the fewest number of questions (4). The aggregate distribution of identical, similar, and unique questions was found to be $31.6 \%$ (42 questions), $31.6 \%$ (42 questions), and $36.8 \%$ (49 questions), respectively. Table 2 lists identical questions, and Table 3 lists unique questions. Despite this relatively even distribution across all gathered questions, the distribution for each individual PRO differed from one another (Fig 2). The KOOS had the highest number of unique questions $(26 / 42,61.9 \%)$, while Tegner held the highest percentage $(11 / 16,68.8 \%)$. The KOS, which was developed from four of the other PROs (the CKRS, Lysholm, WOMAC, and IKDC) ${ }^{15}$, was found to have the highest percentage of identical questions (16/ 25, 64\%). Aside from Marx, the KOS also had the lowest percentage of unique questions $(2 / 25,8 \%)$. All four questions in the Marx scale were similar to those in other PRO scales.

Table 4 lists the most commonly asked questions. Questions about stiffness/swelling, stairs, running, and jumping were included in 5 of the 7 PROs. There was no single question that was included in every PRO. The percentages of both identical and similar questions between different pairs of PROs are shown in Fig 3. All 4 $(100 \%)$ Marx questions overlapped with the KOS and 3
(75\%) questions overlapped with the CKRS. The Lysholm overlapped $75 \%(6 / 8)$ with both the IKDC and KOS. The Lysholm and Tegner, made to complement one another, did not overlap at all. Neither overlapped with the Marx scale as well.

\section{PRO Question Analysis of Domain Coverage}

Fig 4 illustrates each PRO's coverage across different domains. No single PRO assessed all 6 domains of patient outcomes. Instead, each PRO had a distinct question composition that varied across the different domains. The CKRS and KOOS evaluated all domains except Quality of Life and Occupational, respectively. The KOS and IKDC evaluated 4/6 domains, while the Lysholm and Tegner evaluated 3/6. Sports/Recreation was the only domain assessed by all PROs. With the exception of Marx, which only assessed Sports/Recreation, Functional Activities was evaluated in all PROs. The KOOS was the only PRO that evaluated Quality of Life.

\section{Discussion}

There is notable overlap among commonly used patient-administered questionnaires in evaluation of ACL injuries. Within the seven PROs examined in this study, $62.4 \%$ (84 of 133 questions) of questions were found to be identical or similar. This amount of overlap can be reassuring when attempting to compare studies that employ different PROs. Each PRO, however, is distinguished by its pattern of domain coverage. Understanding the strengths and limitations of available PROs will help guide clinicians in selecting the appropriate surveys for their desired goals. 
Table 3. Unique Questions

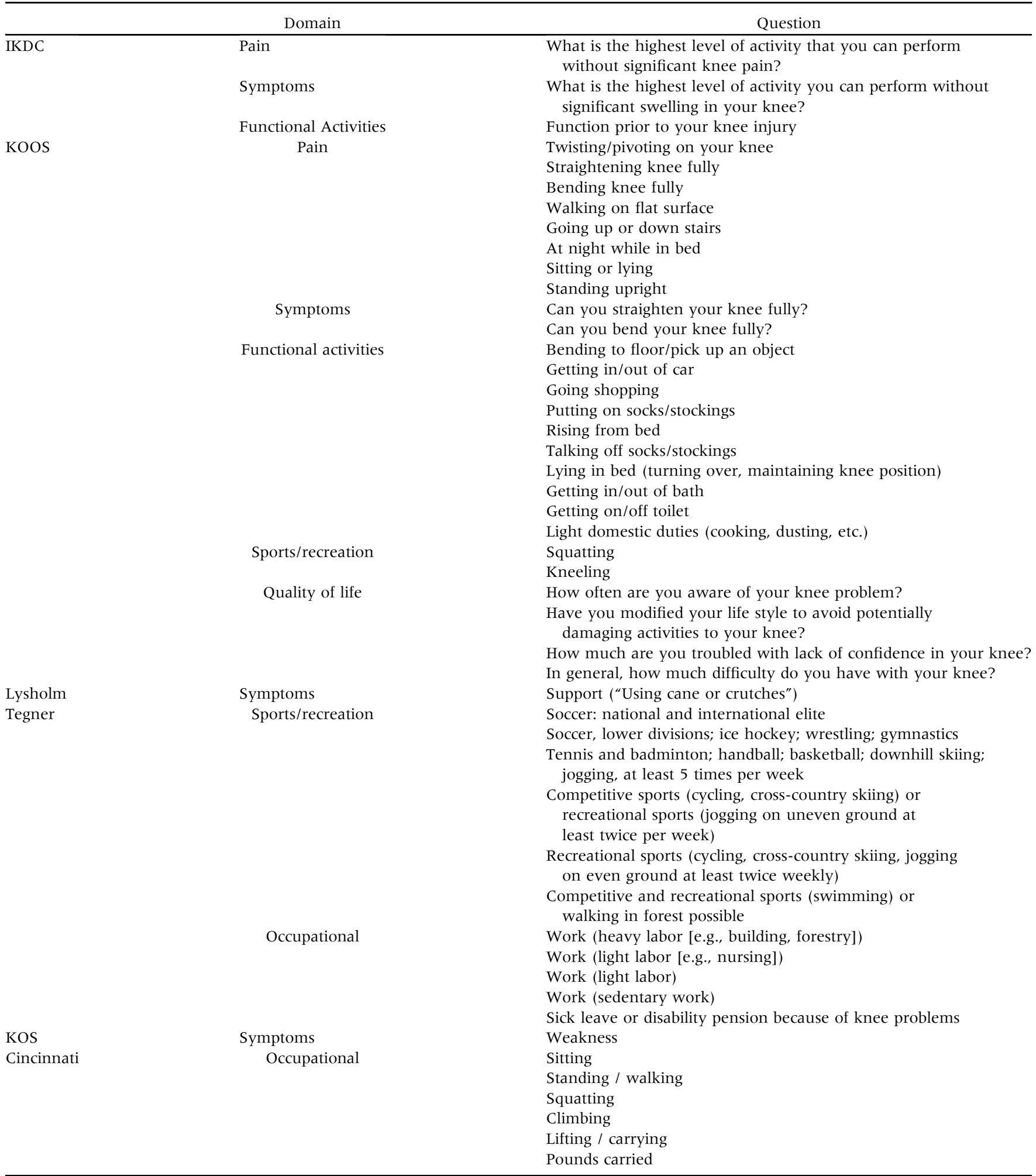

IKDC, International Knee Documentation Committee; KOOS, Knee Injury and Osteoarthritis Outcome Score; KOS, Knee Outcome Survey.

The IKDC and KOOS are the most commonly used today, cited in $69.7 \%$ and $60.5 \%$, respectively, of ACL studies over the past 2 years. Most of the questions asked in the IKDC were found to be identical (47.4\%) or similar $(36.8 \%)$ to another PRO. The KOOS displayed an opposite distribution: $61.9 \%$ of its questions were unique, while only $9.5 \%$ were identical. Incorporated questions from the WOMAC, commonly used 


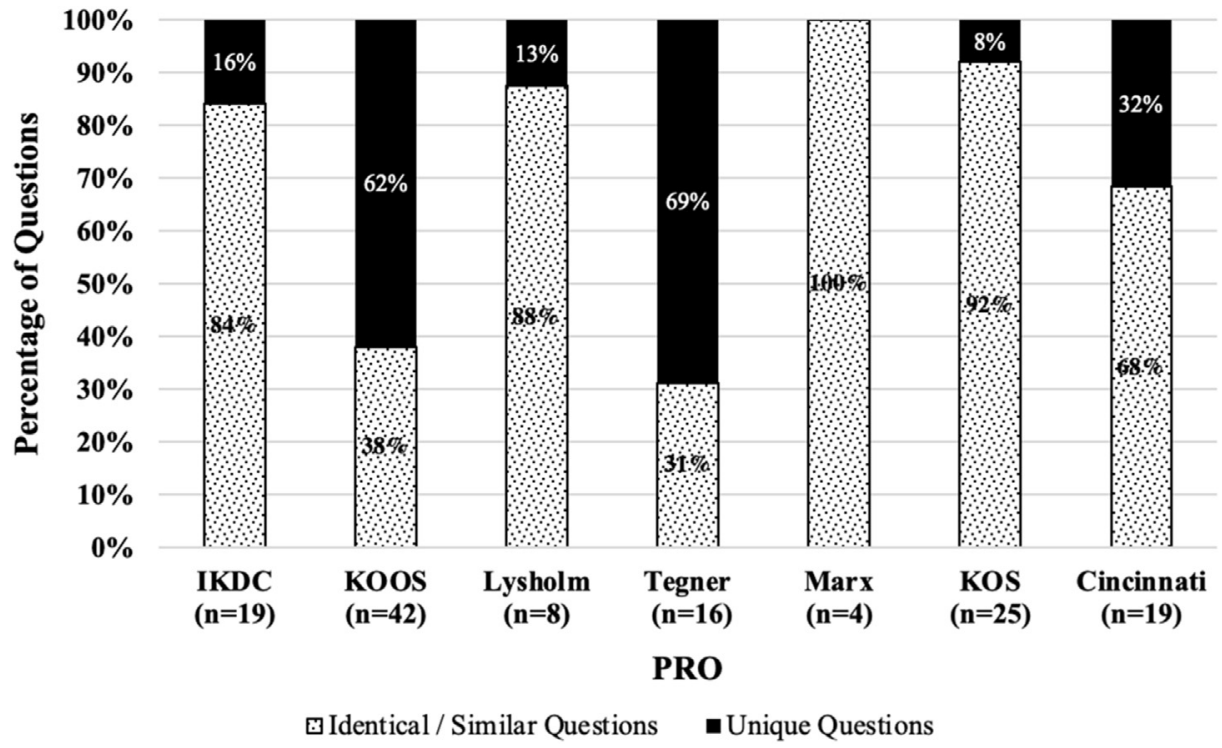

Fig 2. Distributions of overlapping (identical and similar) and unique questions for each patient-reported outcome (PRO) measurement: International Knee Documentation Committee (IKDC) form, Knee Injury and Osteoarthritis Outcome Score (KOOS), Lysholm Knee Scoring Scale, Tegner Activity Scale, Marx Scale, Knee Outcome Survey (KOS), and Cincinnati Knee Rating System (CKRS). for hip and knee osteoarthritis patients, were a large contributor to this uniqueness. Importantly, despite the KOOS covering 5/6 domains and the greatest number of questions among this selection of PROs, it does not include specific items related to instability. This notable absence suggests that KOOS may be more appropriately applied for general knee health.

A 2015 study looked at the various objective and subjective outcomes presented in studies related to ACL reconstruction in four high-impact-factor orthopaedic journals from 2010 through $2014 .^{20}$ Authors similarly found that the IKDC was the most prevalent PRO used, found in $71.4 \%$ of those studies. The Lysholm and Tegner followed with $63 \%$ and $42 \%$, respectively. Interestingly, the KOOS was found to be the fourth most common PRO. Notably, when compared to the preceding 5-year period (2005 through 2009), the KOOS showed the largest increase in usage from $8 \%$ to $20 \% .^{20}$ It is possible that with greater appreciation of patient well-being, the use of KOOS has continued to increase with time. As patient satisfaction draws more attention with increasing clinical and economic implications, ${ }^{21}$ the Quality of Life section of KOOS may be seen as a meaningful advantage.

In the same 2015 review on ACL studies in highimpact factor orthopaedic journals, it was found that most studies reported either two $(41 \%)$ or three $(33 \%)$ PROs. ${ }^{20}$ The 2020 consensus statement agrees with this practice of applying more than one outcome measurement in evaluation of ACL treatment. ${ }^{1}$ Specifically, the consensus recommends the use of at least one kneespecific tool, one health-related quality-of-life tool, and one activity rating scale. ${ }^{1}$ The IKDC Subjective Knee Form is the endorsed knee-specific tool, agreed upon by nearly all (24/25) consensus members. However, the authors add that despite the IKDC being "currently the optimal scale, ... we should be careful not to neglect the other scores." ${ }^{1}$ For sports and activity assessment, the consensus recommends the Marx scale. The consensus statement did not recommend a

Table 4. Most Commonly Asked Questions

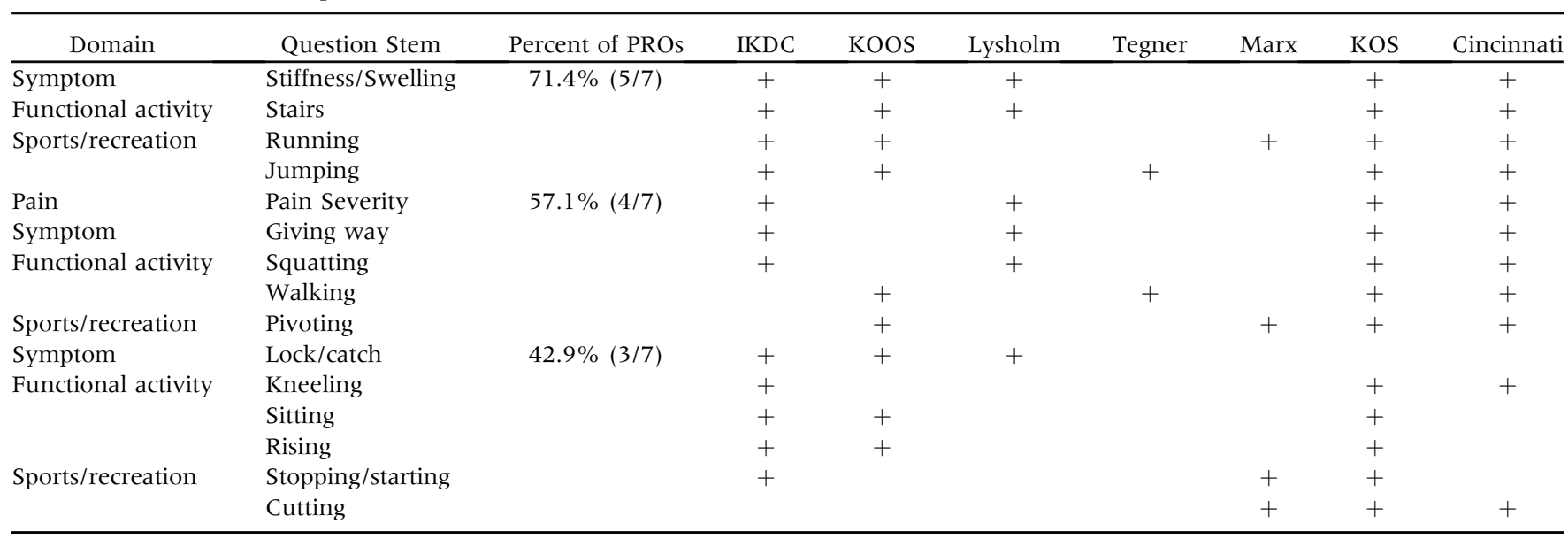




\begin{tabular}{r|ccccccc}
\multicolumn{1}{r}{} & IKDC & KOOS & Lysholm & Tegner & Marx & KOS & Cincinnati \\
\cline { 2 - 8 } IKDC (n=19) & $\mathrm{x}$ & $47.4 \%$ & $36.8 \%$ & $5.3 \%$ & $10.5 \%$ & $63.2 \%$ & $57.9 \%$ \\
KOOS (n=42) & $26.2 \%$ & $\mathrm{x}$ & $14.3 \%$ & $7.1 \%$ & $4.8 \%$ & $31.0 \%$ & $21.4 \%$ \\
Lyshom (n=8) & $75.0 \%$ & $37.5 \%$ & $\mathrm{x}$ & $0.0 \%$ & $0.0 \%$ & $75.0 \%$ & $62.5 \%$ \\
Tegner (n=16) & $12.5 \%$ & $25.0 \%$ & $0.0 \%$ & $\mathrm{x}$ & $0.0 \%$ & $18.8 \%$ & $25.0 \%$ \\
Marx (n=4) & $50.0 \%$ & $50.0 \%$ & $0.0 \%$ & $0.0 \%$ & $\mathrm{x}$ & $100.0 \%$ & $75.0 \%$ \\
KOS (n=25) & $72.0 \%$ & $56.0 \%$ & $52.0 \%$ & $8.0 \%$ & $12.0 \%$ & $\mathrm{x}$ & $68.0 \%$ \\
Cincinnati (n=19) & $52.6 \%$ & $31.6 \%$ & $31.6 \%$ & $15.8 \%$ & $10.5 \%$ & $52.6 \%$ & $\mathrm{x}$ \\
\hline
\end{tabular}

Fig 3. Percentage of overlapping questions between pairs of patient-reported outcome (PROs) measurements for the International Knee Documentation Committee (IKDC) form, Knee Injury and Osteoarthritis Outcome Score (KOOS), Lysholm Knee Scoring Scale, Tegner Activity Scale, Marx Scale, Knee Outcome Survey (KOS), and Cincinnati Knee Rating System (CKRS). The row for each PRO lists the percentage of its total questions that are identical or similar to those of another PRO (column). The denominator for the percentage of overlap is based on the total number of questions for the PRO in that row (indicated by $n$ ). Red color indicates a higher percentage of overlap. Green color indicates a lower percentage of overlap.

particular health-related quality of life measure. However, among their list of possible options, the KOOS is the only PRO analyzed in this study that fulfills the role. The impact of ACL injury on the patient's overall wellbeing should not be overlooked. ${ }^{22}$ The KOOS validation study showed that the quality of life subscale had the highest effect size at 6 months postoperatively for patients who underwent ACL reconstruction. ${ }^{11}$ It is notable that this domain only makes up 9.5\% (4 questions) of the questionnaire.

There are other measures that could instead serve as a health-related quality of life measure, including Quality of Life Outcome Measure for Chronic Anterior Cruciate Ligament Deficiency (ACL-QOL), European Quality of Life-5 dimensions (EQ-5D), Short-Form-36 and -8 health surveys (SF-36, SF-8), Sickness Impact Profile (SIP), and Quality of Well-being (QWB). ${ }^{1}$ Notably, in a systematic review of patients following ACL reconstruction, poorer health-related qualify of life measures were reported using the KOOS Quality of Life subscale than those assessed using a generic health-related qualify of life measure such as SF-36. ${ }^{23}$ The authors added the caveat that only a limited number of studies investigated these factors and would be a valuable direction for future research. Although there are PROs like the KOOS that broadly cover multiple domains, this comprehensive coverage comes with the risk of survey fatigue for patients. A concise and targeted PRO that covers all domains could be validated for patients with ACL and ligamentous injuries to the knee, but that would need to be further studied. It is our recommendation that IKDC and Marx, with the addition of SF-12 if a quality of life measure is desired, be used for the most comprehensive and efficient combination.

\section{Limitations}

There are several limitations to this study. First, only the seven most cited knee-specific PROs for ACL injury were selected for analysis, possibly excluding others that may provide valuable insight. For example, general

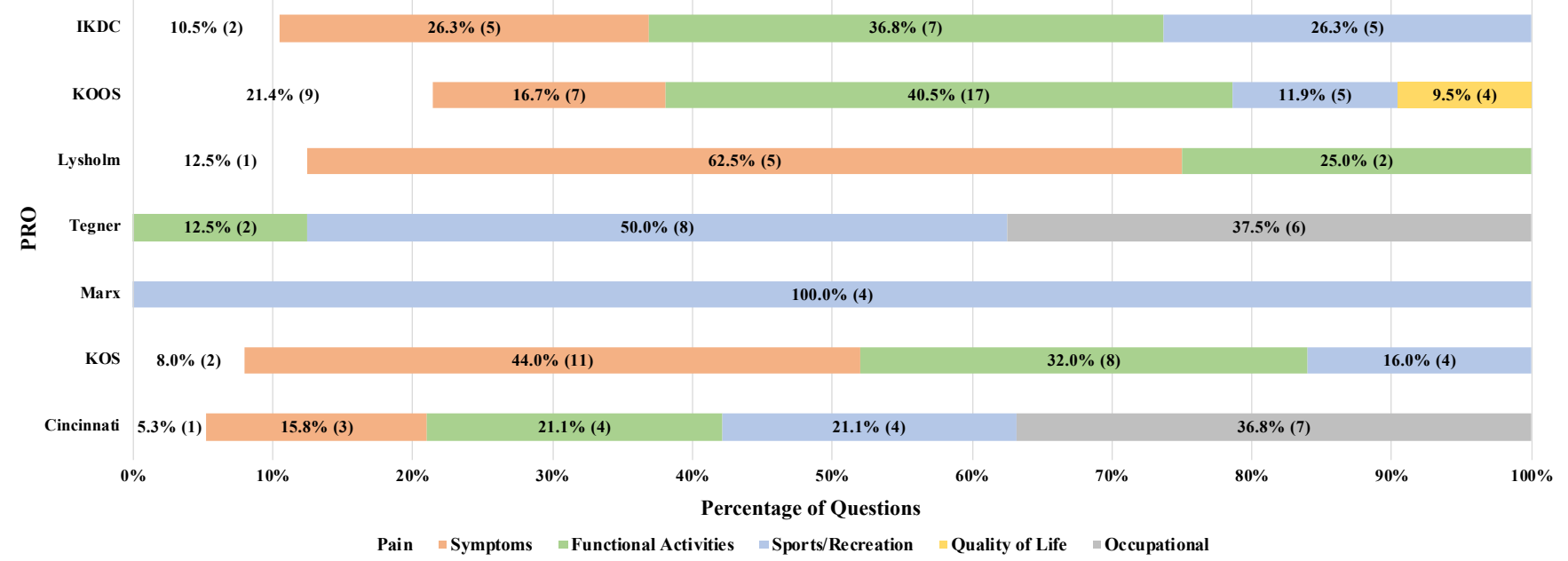

Fig 4. Percentage of question distribution by domain across each patient-reported outcome (PRO) measurement for the International Knee Documentation Committee (IKDC) form, Knee Injury and Osteoarthritis Outcome Score (KOOS), Lysholm Knee Scoring Scale, Tegner Activity Scale, Marx Scale, Knee Outcome Survey (KOS), and Cincinnati Knee Rating System (CKRS). 
health measures such as SF-36 and EQ-5D were not included but could provide supplementary information in evaluation of these patients. Second, the Marx and Tegner activity scores were not intended to be used in isolation. It may not be appropriate to compare the focused nature of these tools to the broader assessments sought by other PROs. Third, the clinician-reported portions of IKDC and CKRS were not included in the present study but may further distinguish these PROs from others. Fourth, the classification of questions as "identical," "similar," or "unique" is not a validated instrument. The classification for each question was agreed upon by all authors without an intra- or interrater reliability analysis performed. Finally, only the questions themselves were analyzed. The question format, answer choices, and scoring systems were not included in this analysis but could certainly impact patient response and score interpretation.

\section{Conclusion}

Nearly two-thirds of questions overlap between the commonly used PROs for ACL injury. Although Sports/ Recreation is assessed by all PROs, each has its own pattern of coverage across this and other domains.

\section{References}

1. Svantesson E, Hamrin Senorski E, Webster KE, et al. Clinical outcomes after anterior cruciate ligament injury: Panther symposium ACL injury clinical outcomes consensus group. Knee Surg Sport Traumatol Arthrosc 2020;28:2415-2434.

2. Lynch AD, Logerstedt DS, Grindem H, et al. Consensus criteria for defining "successful outcome" after ACL injury and reconstruction: A Delaware-Oslo ACL cohort investigation. Br J Sports Med 2015;49:335-342.

3. Black N. Patient reported outcome measures could help transform healthcare. BMJ 2013;346:1-5.

4. Roos EM. Outcome after anterior cruciate liagment reconstruction-A comparison of patients' and surgeons' assessments. Scand J Med Sci Sport 2001;11:287-291.

5. Lavallee DC, Chenok KE, Love RM, et al. Incorporating patient-reported outcomes into health care to engage patients and enhance care. Health Aff 2016;35:575-582.

6. Meta F, Lizzio VA, Jildeh TR, Makhni EC. Which patient reported outcomes to collect after anterior cruciate ligament reconstruction. Ann Jt 2017;2:21-21.

7. Wang D, Jones MH, Khair MM, Miniaci A. Patient-reported outcome measures for the knee. J Knee Surg 2010;23:137-151.

8. Agarwalla A, Puzzitiello RN, Liu JN, et al. Timeline for maximal subjective outcome improvement after anterior cruciate ligament reconstruction. Am J Sports Med 2019;47: 2501-2509.
9. Hefti E, Müller W, Jakob RP, Stäubli HU. Evaluation of knee ligament injuries with the IKDC form. Knee Surg Sport Traumatol Arthrosc 1993;1:226-234.

10. Rossi MJ, Lubowitz JH, Guttmann D. Development and validation of the International Knee Documentation Committee Subjective Knee form. Am J Sports Med 2002;30:152.

11. Roos EM, Roos HP, Lohmander LS, Ekdahl C, Beynnon BD. Knee Injury and Osteoarthritis Outcome Score (KOOS)Development of a self-administered outcome measure. J Orthop Sports Phys Ther 1998;28:88-96.

12. Roos EM, Toksvig-larsen S. Knee Injury and Osteoarthritis Outcome Score (KOOS) - Validation and comparison to the WOMAC in total knee replacement. Health Qual Life Outcomes 2003;1:1-10.

13. Lysholm J, Gillquist J. Evaluation of knee ligament surgery results with special emphasis on use of a scoring scale. Am J Sports Med 1982;10:150-154.

14. Marx RG, Stump TJ, Jones EC, Wickiewicz TL, Warren RF. Development and evaluation of an activity rating scale for disorders of the knee. Am J Sports Med 2001;29:213-218.

15. Irrgang JJ, Snyder-Mackler L, Wainner RS, Fu FH, Harner CD. Development of a patient-reported measure of function of the knee. J Bone Jt Surg A 1998;80:1132-1145.

16. Noyes FR, Mooar PA, Matthews DS, Butler DL. The symptomatic anterior cruciate-deficient knee. Part I. The long-term functional disability in athletically active individuals. J Bone Jt Surg 1983;65:154-162.

17. Noyes FR, Matthews DS, Mooar PA, Grood ES. The symptomatic anterior cruciate knee. Part II. The results of rehabilitation, activity modification, and counseling on functional disability. J Bone Jt Surg 1983;65:163-174.

18. Noyes FR, Barber SD, Mooar LA. A rationale for assessing sports activity levels and limitations in knee disorders. Clin Orthop Relat Res 1989;246:238-249.

19. Barber-Westin SD, Noyes FR, McCloskey JW. Rigorous statistical reliability, validity, and responsiveness testing of the cincinnati knee rating system in 350 subjects with uninjured, injured, or anterior cruciate ligamentreconstructed knees. Am J Sports Med 1999;27:402-416.

20. Makhni EC, Padaki AS, Petridis PD, et al. High variability in outcome reporting patterns in high-impact ACL literature. J Bone Jt Surg Am 2015;97:1529-1542.

21. Ardern CL, Österberg A, Sonesson S, Gauffin H, Webster KE, Kvist J. Satisfaction with knee function after primary anterior cruciate ligament reconstruction is associated with self-efficacy, quality of life, and returning to the preinjury physical activity. Arthroscopy 2016;32:1631-1638.e3.

22. Irrgang JJ, Anderson AF. Development and validation of health-related quality of life measures for the knee. Clin Orthop Relat Res 2002;(402):95-109.

23. Filbay SR, Ackerman IN, Russell TG, Macri EM, Crossley KM. Health-related quality of life after anterior cruciate ligament reconstruction: A systematic review. Am J Sports Med 2014;42:1247-1255. 
International Knee Documentation Committee

(IKDC) Subjective Knee Evaluation Form

\section{IKDC SUBJECTIVE KNEE EVALUATION FORM}

Your Full Name

Today's Date: $\frac{}{\text { Day }} \frac{}{\text { Month }} \overline{\text { Year }}$

Date of Injury: $\frac{}{\text { Day }} \frac{}{\text { Month }} \frac{}{\text { Year }}$

\section{SYMPTOMS*:}

*Grade symptoms at the highest activity level at which you think you could function without significant symptoms, even if you are not actually performing activities at this level.

1. What is the highest level of activity that you can perform without significant knee pain?

aVery strenuous activities like jumping or pivoting as in basketball or soccer

uStrenuous activities like heavy physical work, skiing or tennis

aModerate activities like moderate physical work, running or jogging

口Light activities like walking, housework or yard work

unnable to perform any of the above activities due to knee pain

2. During the past 4 weeks, or since your injury, how often have you had pain?

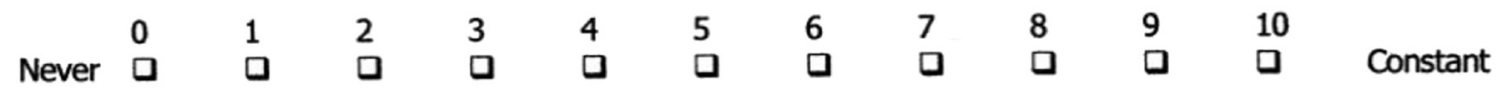

3. If you have pain, how severe is it?

$\begin{array}{cccccccccccc}0 & 1 & 2 & 3 & 4 & 5 & 6 & 7 & 8 & 9 & 10 & \text { Worst pain } \\ \text { No pain } & \square & \square & \square & \square & \square & \square & \square & \square & \square & \square & \begin{array}{l}\text { a } \\ \text { imaginable }\end{array}\end{array}$

4. During the past 4 weeks, or since your injury, how stiff or swollen was your knee?

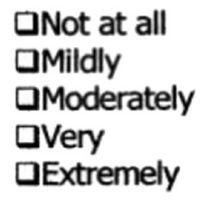

5. What is the highest level of activity you can perform without significant swelling in your knee?

aVery strenuous activities like jumping or pivoting as in basketball or soccer

uStrenuous activities like heavy physical work, skiing or tennis

aModerate activities like moderate physical work, running or jogging

uLight activities like walking, housework, or yard work

uUnable to perform any of the above activities due to knee swelling

6. During the past 4 weeks, or since your injury, did your knee lock or catch?

aYes aNo

7. What is the highest level of activity you can perform without significant giving way in your knee?

aVery strenuous activities like jumping or pivoting as in basketball or soccer

uStrenuous activities like heavy physical work, skiing or tennis

aModerate activities like moderate physical work, running or jogging

DLight activities like walking, housework or yard work

uUnable to perform any of the above activities due to giving way of the knee 


\section{Page 2 - 2000 IKDC SUBJECTIVE KNEE EVALUATION FORM}

\section{SPORTS ACTIVITIES:}

8. What is the highest level of activity you can participate in on a regular basis?

aVery strenuous activities like jumping or pivoting as in basketball or soccer

uStrenuous activities like heavy physical work, skiing or tennis

aModerate activities like moderate physical work, running or jogging

口ight activities like walking, housework or yard work

口Unable to perform any of the above activities due to knee

9. How does your knee affect your ability to:

\begin{tabular}{|l|l|c|c|c|c|c|}
\hline & $\begin{array}{c}\text { Not difficult } \\
\text { at all }\end{array}$ & $\begin{array}{c}\text { Minimally } \\
\text { difficult }\end{array}$ & $\begin{array}{c}\text { Moderately } \\
\text { Difficult }\end{array}$ & $\begin{array}{c}\text { Extremely } \\
\text { difficult }\end{array}$ & $\begin{array}{c}\text { Unable } \\
\text { to do }\end{array}$ \\
\hline a. & Go up stairs & $\square$ & $\square$ & $\square$ & $\square$ & $\square$ \\
\hline b. & Go down stairs & $\square$ & $\square$ & $\square$ & $\square$ & $\square$ \\
\hline c. & Kneel on the front of your knee & $\square$ & $\square$ & $\square$ & $\square$ & $\square$ \\
\hline d. & Squat & $\square$ & $\square$ & $\square$ & $\square$ & $\square$ \\
\hline e. & Sit with your knee bent & $\square$ & $\square$ & $\square$ & $\square$ & $\square$ \\
\hline f. & Rise from a chair & $\square$ & $\square$ & $\square$ & $\square$ & $\square$ \\
\hline g. & Run straight ahead & $\square$ & $\square$ & $\square$ & $\square$ & $\square$ \\
\hline h. & Jump and land on your involved leg & $\square$ & $\square$ & $\square$ & $\square$ & $\square$ \\
\hline i. & Stop and start quickly & $\square$ & $\square$ & $\square$ & $\square$ & $\square$ \\
\hline
\end{tabular}

\section{FUNCTION:}

10. How would you rate the function of your knee on a scale of 0 to 10 with 10 being normal, excellent function and 0 being the inability to perform any of your usual daily activities which may include sports?

FUNCTION PRIOR TO YOUR KNEE INJURY:

Cannot perform

daily activities

$\begin{array}{llll}0 & 1 & 2 & 3 \\ \square & 0 & \square & 0\end{array}$

\section{4}

व
5

व

CURRENT FUNCTION OF YOUR KNEE:

Cannot perform

daily activities

$\begin{array}{llll}0 & 1 & 2 & 3 \\ 0 & 0 & \square & 0\end{array}$

3

4

5

6

7

89

9

No limitation

10 in daily

a activities

No limitation

10 in daily

a activities 


\section{KOOS KNEE SURVEY}

Today's date:

1 Date of birth: 1

Name:

INSTRUCTIONS: This survey asks for your view about your knee. This information will help us keep track of how you feel about your knee and how well you are able to perform your usual activities.

Answer every question by ticking the appropriate box, only one box for each question. If you are unsure about how to answer a question, please give the best answer you can.

\section{Symptoms}

These questions should be answered thinking of your knee symptoms during the last week.

S1. Do you have swelling in your knee?
Never
Rarely
Sometimes
Often
Always
口
口
口
口
口

S2. Do you feel grinding, hear clicking or any other type of noise when your knee moves?
Never
Rarely
Sometimes
Often
Always

S3. Does your knee catch or hang up when moving?
Never
Rarely
Sometimes
Often
Always
口
口
口
口
口

S4. Can you straighten your knee fully?
Always
Often
Sometimes
Rarely
Never

S5. Can you bend your knee fully?
Always
Often
Sometimes
Rarely
Never
ㅁ
口
口
口
口

\section{Stiffness}

The following questions concern the amount of joint stiffness you have experienced during the last week in your knee. Stiffness is a sensation of restriction or slowness in the ease with which you move your knee joint.

S6. How severe is your knee joint stiffness after first wakening in the morning?
None
Mild
Moderate
Severe
Extreme

S7. How severe is your knee stiffness after sitting, lying or resting later in the day?
None
Mild
Moderate
Severe
Extreme 
Pain

P1. How often do you experience knee pain?
Never
Monthly
Weekly
Daily
Always
ㅁ
ㅁ
口
口

What amount of knee pain have you experienced the last week during the following activities?

P2. Twisting/pivoting on your knee

$\begin{array}{ccccc}\text { None } & \text { Mild } & \text { Moderate } & \text { Severe } & \text { Extreme } \\ \mathbf{\square} & \boldsymbol{\square} & \boldsymbol{Q} & \boldsymbol{\square} & \boldsymbol{\square}\end{array}$

P3. Straightening knee fully
None
Mild
Moderate
Severe
Extreme
ㅁ
口
口
口
口

P4. Bending knee fully

$\begin{array}{ccccc}\text { None } & \text { Mild } & \text { Moderate } & \text { Severe } & \text { Extreme } \\ \mathbf{\square} & \boldsymbol{\square} & \boldsymbol{\square} & \boldsymbol{\square} & \boldsymbol{\square}\end{array}$

P5. Walking on flat surface None Mild

口

Severe

Extreme

P6. Going up or down stairs

None

Mild

口

口

Moderate

Severe

Extreme

P7. At night while in bed
None
Mild
口
口

Moderate

Severe

Extreme

口

口

口

P8. Sitting or lying None

Mild

Moderate

Severe

Extreme

P9. Standing upright

None

Mild

Moderate

Severe

Extreme

口

口

口

口

$\square$

\section{Function, daily living}

The following questions concern your physical function. By this we mean your ability to move around and to look after yourself. For each of the following activities please indicate the degree of difficulty you have experienced in the last week due to your knee.
A1. Descending stairs

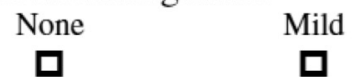
Moderate
Severe
Extreme

A2. Ascending stairs None Mild 口

Moderate

Severe

Extreme 
For each of the following activities please indicate the degree of difficulty you have experienced in the last week due to your knee.

A3. Rising from sitting

None

Mild

口

A4. Standing

None

ㅁ

Mild

口
Moderate

口

Moderate

口
A5. Bending to floor/pick up an object
None

ㅁ
Mild

口
Moderate

ㅁ
Severe

Severe

口

Severe

口

Severe

Moderate

Mild

None

口

None

口

Mild

ㅁ

A8. Going shopping

None

Mild

ㅁ

A9. Putting on socks/stockings

None Mild

口

口

A10. Rising from bed

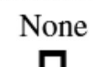

Moderate

口

Moderate

口

Moderate

口

Moderate

口
Severe

口

Severe

Extreme

口

Extreme

Severe

口
Mild

口

A11. Taking off socks/stockings

None

Mild

口

A12. Lying in bed (turning over, maintaining knee position)

None

Mild

口

Moderate

Moderate

口

Moderate

Mild

None

ㅁ

口

A14. Sitting

None

Mild

口

口

A15. Getting on/off toilet

None

Mild

口

口
Moderate

口
Severe

Severe

口

Severe

口

Severe

Severe

口

Severe

Extreme

ㅁ

口

口

Extreme

口

Extreme

$\square$

treme

Extreme

口 
For each of the following activities please indicate the degree of difficulty you have experienced in the last week due to your knee.

A16. Heavy domestic duties (moving heavy boxes, scrubbing floors, etc)
None
Mild
Moderate
Severe
Extreme

A17. Light domestic duties (cooking, dusting, etc)
None
Mild
Moderate
Severe
Extreme

Function, sports and recreational activities

The following questions concern your physical function when being active on a higher level. The questions should be answered thinking of what degree of difficulty you have experienced during the last week due to your knee.

SP1. Squatting

None

SP2. Running

None

Mild

Mild

口

口

口

Mild

None

Mild

Moderate

Severe

Extreme

SP4. Twisting/pivoting on your injured knee

None Mild Moderate

[

口

口

SP5. Kneeling

None

Mild

Moderate

Severe

Extreme
Severe Extreme

$\square$
口

\section{Quality of Life}

Q1. How often are you aware of your knee problem?

$\begin{array}{ccccc}\text { Never } & \text { Monthly } & \text { Weekly } & \text { Daily } & \text { Constantly } \\ \mathbf{0} & \boldsymbol{\square} & \boldsymbol{Q} & \boldsymbol{\square} & \mathbf{\square}\end{array}$

Q2. Have you modified your life style to avoid potentially damaging activities to your knee?

Not at all

Mildly

Moderately

Severely

Totally

口

口

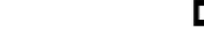

Q3. How much are you troubled with lack of confidence in your knee?

$\begin{array}{cccc}\text { Not at all Mildly } & \text { Moderately } & \text { Severely } & \text { Extremely }\end{array}$

Q4. In general, how much difficulty do you have with your knee?
None
Mild
Moderate
Severe
Extreme

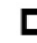

口

口

口

口 


\section{LYSHOLM KNEE SCORING SCALE}

Instructions: Below are common complaints which people frequently have with their knee problems. Please check the statement which best describes your condition.

I. LIMP:

I have no limp when I walk. (5)

I have a slight or periodical limp when I walk. (3)

I have a severe and constant limp when I walk. (0)

II. USING CANE OR CRUTCHES

I do not use a cane or crutches. (5)

I use a cane or crutches with some weight-bearing. (2)

Putting weight on my hurt leg is impossible. (0)

III. LOCKING SENSATION IN THE KNEE

I have no locking and no catching

sensations in my knee. (15)

I have catching sensation but no

locking sensation in my knee. (10)

My knee locks occasionally. (6)

My knee locks frequently. (2)

My knee feels locked at this moment. (0)

IV. GIVING WAY SENSATION FROM THE KNEE

My knee never gives way. (25)

My knee rarely gives way, only during athletics or other vigorous activities. (20)

My knee frequently gives way during athletics or other vigorous activities, in turn I am unable to participate in these activities. (15)

My knee occasionally gives way during daily activities. (10)

My knee often gives way during daily activities. (5)

My knee gives way every step I take. (0)
V. PAIN:

I have no pain in my knee. (25)

I have intermittent or slight pain in my knee

during vigorous activities. (20)

I have marked pain in my knee during vigorous activities. (15)

I have marked pain in my knee during or after walking more than 1 mile. (10)

I have marked pain in my knee during or after walking less than 1 mile. (5)

I have constant pain in my knee. (0)

VI. SWELLING

I have no swelling in my knee. (10)

I have swelling in my knee only after vigorous activities. (6)

I have swelling in my knee after ordinary activities. (2)

I have swelling constantly in my knee. (0)

VII. CLIMBING STAIRS:

I have no problems climbing stairs. (10)

I have slight problems climbing stairs. (6)

I can climb stairs only one at a time. (2)

Climbing stairs is impossible for me. (0)

VIII. SQUATTING

I have no problems squatting. (5)

I have slight problems squatting. (4)

I can not squat beyond a 90 degree bend in my

knee. (2)

Squatting is impossible because of my knee. (0) 
Tegner Activity Scale

\begin{tabular}{|c|c|c|c|}
\hline $\begin{array}{l}\text { Activity Level } \\
\text { Before Injury }\end{array}$ & $\begin{array}{c}\text { Current } \\
\text { Activity Level }\end{array}$ & $\begin{array}{l}\text { Activity Level } \\
\text { Following } \\
\text { Surgery } \\
\text { if applicable }\end{array}$ & \\
\hline & & & $\begin{array}{l}\text { Competitive sports } \\
\text { Soccer - national and international elite }\end{array}$ \\
\hline & & & $\begin{array}{l}\text { Competitive sports } \\
\text { Soccer, lower divisions } \\
\text { Ice hockey } \\
\text { Wrestling } \\
\text { Gymnastics }\end{array}$ \\
\hline & & & $\begin{array}{l}\text { Competitive sports } \\
\text { Bandy } \\
\text { Squash or badminton } \\
\text { Athletics (jumping, etc.) } \\
\text { Downhill skiing }\end{array}$ \\
\hline & & & $\begin{array}{l}\text { Competitive sports } \\
\text { Tennis } \\
\text { Athletics (running) } \\
\text { Motorcross, speedway } \\
\text { Handball } \\
\text { Basketball } \\
\text { Recreational sports } \\
\text { Soccer } \\
\text { Bandy and ice hockey } \\
\text { Squash } \\
\text { Athletics (jumping) } \\
\text { Cross-country track findings both recreational and competitive }\end{array}$ \\
\hline & & & $\begin{array}{l}\text { Recreational sports } \\
\text { Tennis and badminton } \\
\text { Handball } \\
\text { Basketball } \\
\text { Downhill skiing } \\
\text { Jogging, at least five times per week }\end{array}$ \\
\hline & & & $\begin{array}{l}\text { Work Heavy labor (e.g., building, forestry) } \\
\text { Competitive sports } \\
\quad \text { Cycling } \\
\quad \text { Cross-country skiing } \\
\text { Recreational sports } \\
\quad \text { Jogging on uneven ground at least twice weekly }\end{array}$ \\
\hline & & & $\begin{array}{l}\text { Work Moderately heavy labor (e.g., truck driving, heavy domestic work) } \\
\text { Recreational sports } \\
\text { Cycling } \\
\text { Cross-country skiing } \\
\text { Jogging on even ground at least twice weekly }\end{array}$ \\
\hline & & & $\begin{array}{l}\text { Work Light labor (e.g., nursing) } \\
\text { Competitive and recreational sports } \\
\quad \text { Swimming } \\
\text { Walking in forest possible }\end{array}$ \\
\hline & & & $\begin{array}{l}\text { Work Light labor } \\
\text { Walking on uneven ground possible but impossible to walk in forest }\end{array}$ \\
\hline & & & $\begin{array}{l}\text { Work Sedentary work } \\
\text { Walking on even ground possible }\end{array}$ \\
\hline & & 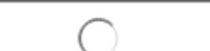 & Sick leave or disability pension because of knee problems \\
\hline
\end{tabular}




\section{Marx Scale}

\section{MARX SCALE (ENGLISH VERSION)}

Please indicate how often you performed each activity in your healthiest and most active state, in the past year. Kindly put a $(\square)$ mark on the appropriate space after each item.

\begin{tabular}{|l|c|c|c|c|c|}
\hline & $\begin{array}{l}\text { Less than } \\
\text { one time in } \\
\text { a month }\end{array}$ & $\begin{array}{l}\text { One time in } \\
\text { a month }\end{array}$ & $\begin{array}{l}\text { One time } \\
\text { in a week }\end{array}$ & $\begin{array}{l}\text { 2 or 3 times } \\
\text { in a week }\end{array}$ & $\begin{array}{l}4 \text { or more times in } \\
\text { a week }\end{array}$ \\
\hline $\begin{array}{l}\text { Running: running while } \\
\text { playing a sport or jogging }\end{array}$ & 0 & 1 & 2 & 3 & 4 \\
\hline $\begin{array}{l}\text { Cutting: changing } \\
\text { directions while running }\end{array}$ & 0 & 1 & 2 & 3 & 4 \\
\hline $\begin{array}{l}\text { Deceleration: coming to a } \\
\text { quick stop while running }\end{array}$ & 0 & 1 & 2 & 3 & 4 \\
\hline $\begin{array}{l}\text { Pivoting: turning your } \\
\text { body with your foot } \\
\text { planted while playing } \\
\text { sport; For example: } \\
\text { skiing, skating, kicking, } \\
\text { throwing, hitting a ball } \\
\text { (golf, tennis, squash), etc. }\end{array}$ & 0 & 1 & 2 & 3 & \\
\hline
\end{tabular}


Knee Outcome Survey (KOS)

\section{Knee Outcome Survey Activities of Daily Living Scale (ADLS).}

Symptoms: To what degree does each of the following symptoms affect your level of activity? (check one answer on each line)

\begin{tabular}{|c|c|c|c|c|c|c|}
\hline & $\begin{array}{l}\text { I do not have } \\
\text { the symptom }\end{array}$ & $\begin{array}{l}\text { I have the } \\
\text { symptom, but } \\
\text { it does not } \\
\text { affect my } \\
\text { activity }\end{array}$ & $\begin{array}{l}\text { The symptom } \\
\text { affects my } \\
\text { activity } \\
\text { slightly }\end{array}$ & $\begin{array}{l}\text { The symptom } \\
\text { affects my } \\
\text { activity } \\
\text { moderately }\end{array}$ & $\begin{array}{l}\text { The symptom } \\
\text { affects my } \\
\text { activity } \\
\text { severely }\end{array}$ & $\begin{array}{l}\text { The symptom } \\
\text { prevents me } \\
\text { from all daily } \\
\text { activity }\end{array}$ \\
\hline \multicolumn{7}{|l|}{ Pain } \\
\hline \multicolumn{7}{|l|}{ Stiffness } \\
\hline \multicolumn{7}{|l|}{ Swelling } \\
\hline \multicolumn{7}{|c|}{$\begin{array}{l}\text { Giving way, } \\
\text { buckling, or } \\
\text { shifting of the } \\
\text { knee }\end{array}$} \\
\hline \multicolumn{7}{|l|}{ Weakness } \\
\hline Limping & & & & & & \\
\hline
\end{tabular}


Functional Limitations With Activities of Daily Living: How does your knee affect your ability to: (check one answer on each line)

\begin{tabular}{llllll}
\hline $\begin{array}{l}\text { Activity is not } \\
\text { difficult }\end{array}$ & $\begin{array}{l}\text { Activity is } \\
\text { minimally } \\
\text { difficult }\end{array}$ & $\begin{array}{l}\text { Activity is } \\
\text { somewhat } \\
\text { difficult }\end{array}$ & $\begin{array}{l}\text { Activity is } \\
\text { fairly difficult }\end{array}$ & $\begin{array}{l}\text { Activity is very } \\
\text { difficult }\end{array}$ & $\begin{array}{l}\text { I am unable to } \\
\text { do the activity }\end{array}$ \\
\hline
\end{tabular}

\section{$\underline{\text { Walk }}$}

Go up stairs

Go down

stairs

Stand

Kneel on front

of your knee

Squat

Sit with your

knee bent

Rise from a

chair

Scoring: The first column is scored 5 points for each item, followed in successive columns by scores of 4 , $3,2,1$, and 0 for the last column. The total points from all items are summed, then divided by 70 and multiplied by 100 for the ADLS score. For example, if the individual places marks for 12 items in the first column, and 2 items in the second column the total points would be $12 \times 5=60$ points, plus $2 \times 4=8$ points, for a total of 68 points. The ADLS score would then be $68 / 70 \times 100=97 \%$.

\section{Knee Outcome Survey Sports Activities Scale (SAS).}

Symptoms: To what degree does each of the following symptoms affect your level of sports activity? (check one answer on each line)

\begin{tabular}{|c|c|c|c|c|c|c|}
\hline & Never have & $\begin{array}{l}\text { Have, but does } \\
\text { not affect my } \\
\text { sports activity }\end{array}$ & $\begin{array}{l}\text { Affects sports } \\
\text { activity } \\
\text { slightly }\end{array}$ & $\begin{array}{l}\text { Affects sports } \\
\text { activity } \\
\text { moderately }\end{array}$ & $\begin{array}{l}\text { Affects sports } \\
\text { activity } \\
\text { severely }\end{array}$ & $\begin{array}{l}\text { Prevents me } \\
\text { from all sports } \\
\text { activity }\end{array}$ \\
\hline \multicolumn{7}{|l|}{ Pain } \\
\hline \multicolumn{7}{|l|}{$\begin{array}{l}\text { Grinding or } \\
\text { grating }\end{array}$} \\
\hline \multicolumn{7}{|l|}{ Stiffness } \\
\hline \multicolumn{7}{|l|}{ Swelling } \\
\hline \multicolumn{7}{|c|}{$\begin{array}{l}\text { Slipping or } \\
\text { partial giving } \\
\text { way of knee }\end{array}$} \\
\hline \multicolumn{7}{|c|}{$\begin{array}{l}\text { Buckling or } \\
\text { full giving way } \\
\text { of knee }\end{array}$} \\
\hline Weakness & & & & & & \\
\hline
\end{tabular}


Functional Limitations With Sports Activities: How does your knee affect your ability to: (check one answer on each line)

\begin{tabular}{ccccc}
\hline $\begin{array}{c}\text { Not difficult } \\
\text { at all }\end{array}$ & $\begin{array}{c}\text { Minimally } \\
\text { difficult }\end{array}$ & $\begin{array}{c}\text { Somewhat } \\
\text { difficult }\end{array}$ & Fairly difficult & Very difficult Unable to do \\
\hline
\end{tabular}

Run straight

ahead

Jump and land

on your

involved leg

Stop and start

quickly

Cut and pivot

on your

involved leg

Scoring: The first column is scored 5 points for each item, followed in successive columns by scores of 4 , $3,2,1$, and 0 for the last column. The total points from all items are summed, then divided by 55 and multiplied by 100 for the SAS score. For example, if the individual places marks for 9 items in the first column, and 2 items in the second column the total points would be $9 \times 5=45$ points, plus $2 \times 4=8$ points, for a total of 53 points. The SAS score would then be $53 / 55 \times 100=96 \%$. 


\section{Cincinnati Knee Rating System (CKRS)}

\section{Appendix I. Cincinnati Knee Rating System: Symptom Rating Scales, Patient Perception Scale}

DIRECTIONS: Using the key below, circle the appropriate boxes on the four scales below which indicate the highest level you can reach WITHOUT having symptoms.

\section{Scale Description}

10 Normal knee, able to do strenuous work/sports with jumping, hard pivoting

8 Able to do moderate work/sports with running, turning and twisting; symptoms with strenuous work/sports

6 Able to do light work/sports with no running, twisting or jumping; symptoms with moderate work/sports

4 Able to do activities of daily living alone; symptoms with light work/sports

2 Moderate symptoms (frequent, limiting) with activities of daily living

0 Severe symptoms (constant, not relieved) with activities of daily living

1. PAIN

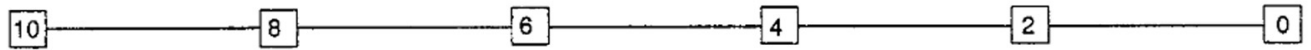

2. SWELLING (actual fluid in the knee; obvious puffiness)

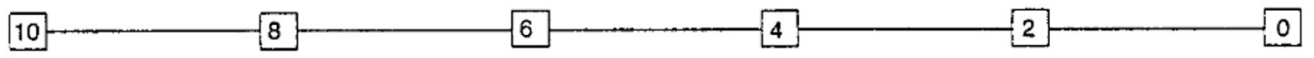

3. PARTIAL GIVING-WAY (partial knee collapse, no fall to the ground)

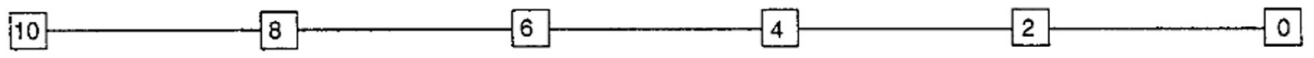

4. FULL GIVING-WAY (knee collapse occurs with actual falling to the ground)
10
6
4
2
0

Patient Grade: Rate the overall condition of your knee at the present time. Circle one number below.

\begin{tabular}{|cccccccccc|}
\hline 1 & 2 & 3 & 4 & 5 & 6 & 7 & 8 & 9 & 10 \\
poor & good & 4 & normal \\
\hline
\end{tabular}

poor - I have significant limitations that affect activities of daily living.

fair -- I have moderate limitations that affect activities of daily living, no sports possible.

good -- I have some limitations with sports but I can participate; I compensate

normal/excellent -- I am able to do whatever I wish (any sport) with no problems. 


\section{Appendix II. Cincinnati Knee Rating System:}

Sports Activity Scale, Activities of Daily Living Function Scales, Sports Function Scales

\section{Sports Activity Scale}

Level I (participates 4-7 days/week)

100 Jumping, hard pivoting, cutting (basketball, volleyball, football, gymnastics, soccer)

95 Running, twisting, turning (tennis, racquetball, handball, ice hockey, field hockey, skiing, wrestling)

90 No running, twisting, jumping (cycling, swimming)

Level II (participates 1-3 days/week)

85 Jumping, hard pivoting, cutting (basketball, volleyball, football, gymnastics, soccer)

80 Running, twisting, turning (tennis, racquetball, handball, ice hockey, field hockey, skiing, wrestling)

75 No running, twisting, jumping (cycling, swimming)

Level III (participates 1-3 times/month)

65 Jumping, hard pivoting, cutting (basketball, volleyball, football, gymnastics, soccer)

60 Running, twisting, turning (tennis, racquetball, handball, ice hockey, field hockey, skiing, wrestling)

55 No running, twisting, jumping (cycling, swimming)

Level IV (no sports)

401 perform activities of daily living without problems

20 I have moderate problems with activities of daily living

0 I have severe problems with activities of daily living; on crutches, full disability

\section{Activities of Daily Living Function Scales}

\section{Walking}

check one box:

${ }_{40} \square$ normal, unlimited

$30 \square$ some limitations

$20 \square$ only 3-4 blocks possible

o[ less than 1 block; cane, crutch

\section{Sports Function Scales}

\section{Straight running}

check one box: $100 \square$ fully competitive so $\square$ some limitations, guarding $60 \square$ definite limitations, half speed ${ }_{40} \square$ not able to do

\section{Stairs}

check one box:

40 $\square$ normal, unlimited

$30 \square$ some limitations

$20 \square$ only $11-30$ steps possible

$\circ \square$ only $1-10$ steps possible

\section{Jumping / landing on affected leg check one box: $100 \square$ fully competitive ${ }_{80} \square$ some limitations, guarding $60 \square$ definite limitations, half speed} 40 $\square$ not able to do

\section{Squatting / kneeling check one box: 40 $\square$ normal, unlimited $30 \square$ some limitations $20 \square$ only $6-10$ possible $o \square$ only $0-5$ possible}

\section{Hard twists / cuts / pivots}

check one box: ${ }_{100} \square$ fully competitive so $\square$ some limitations, guarding ${ }_{60} \sqcup$ definite limitations, half speed ${ }_{40} \square$ not able to do 
Appendix III. Cincinnati Knee Rating System: Occupational Rating Scale

\begin{tabular}{|c|c|c|c|c|c|c|}
\hline \multicolumn{4}{|c|}{ Check the response which best describes what you actually do at work. } & \multicolumn{2}{|c|}{ Check only one response per column. } & $\begin{array}{r}\text { Total Points } \\
\times 2=\end{array}$ \\
\hline $\begin{array}{l}\text { Factor } 1 \\
\text { sitting }\end{array}$ & $\begin{array}{c}\text { Factor } 2 \\
\text { standing/ } \\
\text { walking }\end{array}$ & $\begin{array}{c}\text { Factor } 3 \\
\text { walking on } \\
\text { uneven ground }\end{array}$ & $\begin{array}{l}\text { Factor } 4 \\
\text { squatting }\end{array}$ & $\begin{array}{l}\text { Factor } 5 \\
\text { climbing }\end{array}$ & $\begin{array}{c}\text { Factor } 6 \\
\text { lifting/carrying }\end{array}$ & $\begin{array}{c}\text { Factor } 7 \\
\text { pounds carried }\end{array}$ \\
\hline $\begin{array}{l}o \square 8-10 \\
\text { hrs/day }\end{array}$ & $\circ \square 0$ & $\circ \square 0_{\text {hr/day }}^{0}$ & $\begin{array}{l}\circ \square 0 \\
\text { times/day }\end{array}$ & $\begin{array}{l}\circ \square 0 \\
\quad \text { times/day }\end{array}$ & $\begin{array}{l}\circ \square 0 \\
\text { times/day }\end{array}$ & $\circ 0.5 \mathrm{lbs}$ \\
\hline $\begin{array}{l}\square 6-7 \\
\text { hrs/day }\end{array}$ & ${ }^{2} \square 1$ & ${ }^{2} \square 1$ & $\begin{array}{l}\square \square \\
\text { times/day }\end{array}$ & $\begin{array}{l}2 \square 1 \text { flight, } \\
2 \text { times/day }\end{array}$ & $\begin{array}{l}\quad \square 1-5 \\
\text { times/day }\end{array}$ & $\square 6-10 \mathrm{lbs}$ \\
\hline $\begin{array}{l}2 \square \text { 4-5 } \\
\text { hrs/day }\end{array}$ & $\begin{array}{l}{ }_{4} \square 2-3 \\
\text { hrs/day }\end{array}$ & $\begin{array}{l}{ }_{4} \square \text { 2-3 } \\
\text { hrs/day }\end{array}$ & $\begin{array}{l}2 \square] 6-10 \\
\text { times/day }\end{array}$ & $\begin{array}{l}4 \square 3 \text { flights, } \\
2 \text { times/day }\end{array}$ & $\begin{array}{l}2 \square \text { 6-10 } \\
\quad \text { times/day }\end{array}$ & $2 \square 11-20 \mathrm{lbs}$ \\
\hline $\begin{array}{l}{ }_{3} \square \text { 2-3 } \\
\text { hrs/day }\end{array}$ & $\begin{array}{l}{ }_{6} \square \text { 4-5 } \\
\text { hrs/day }\end{array}$ & $\begin{array}{l}6 \square \text { 4-5 } \\
\text { hrs/day }\end{array}$ & $\begin{array}{l}{ }_{3} \square 11-15 \\
\text { times/day }\end{array}$ & $\begin{array}{c}6 \square 10 \text { flights/ } \\
\text { ladders }\end{array}$ & $\begin{array}{l}3 \square 11-15 \\
\text { times/day }\end{array}$ & ${ }_{3} \square 21-25 \mathrm{lbs}$ \\
\hline $\begin{array}{l}\square_{\mathrm{hr} / \text { day }}\end{array}$ & $\begin{array}{l}a \square \text { 6-7 } \\
\text { hrs/day }\end{array}$ & $\begin{array}{l}{ }_{8} \square 6-7 \\
\text { hrs/day }\end{array}$ & $\begin{array}{l}4 \square \text { 16-20 } \\
\text { times/day }\end{array}$ & $\begin{array}{c}{ }_{8} \square \text { ladders with } \\
\text { weight } 2-3 \\
\text { days/week }\end{array}$ & $\begin{array}{l}4\left[\begin{array}{l}16-20 \\
\text { times/day }\end{array}\right.\end{array}$ & $4 \square$ 26-30 lbs \\
\hline${ }^{4}\left[\begin{array}{l}0 \\
\\
\\
\mathrm{hr} / \mathrm{day}\end{array}\right.$ & $\begin{array}{l}{ }_{10} \square \text { 8-10 } \\
\text { hrs/day }\end{array}$ & $\begin{array}{l}{ }^{10} \square \text { 8-10 } \\
\text { hrs/day }\end{array}$ & $\begin{array}{l}{ }_{5} \square \text { more than } \\
20 \text { times/day }\end{array}$ & $\begin{array}{c}10 \square \text { ladders daily } \\
\text { with weight }\end{array}$ & $\begin{array}{l}{ }_{5} \square \text { more than } \\
20 \text { times/day }\end{array}$ & $\begin{array}{c}{ }^{5} \square \text { more than } \\
30 \text { lbs }\end{array}$ \\
\hline
\end{tabular}


Appendix IV. Cincinnati Knee Rating System: Overall Rating Scheme

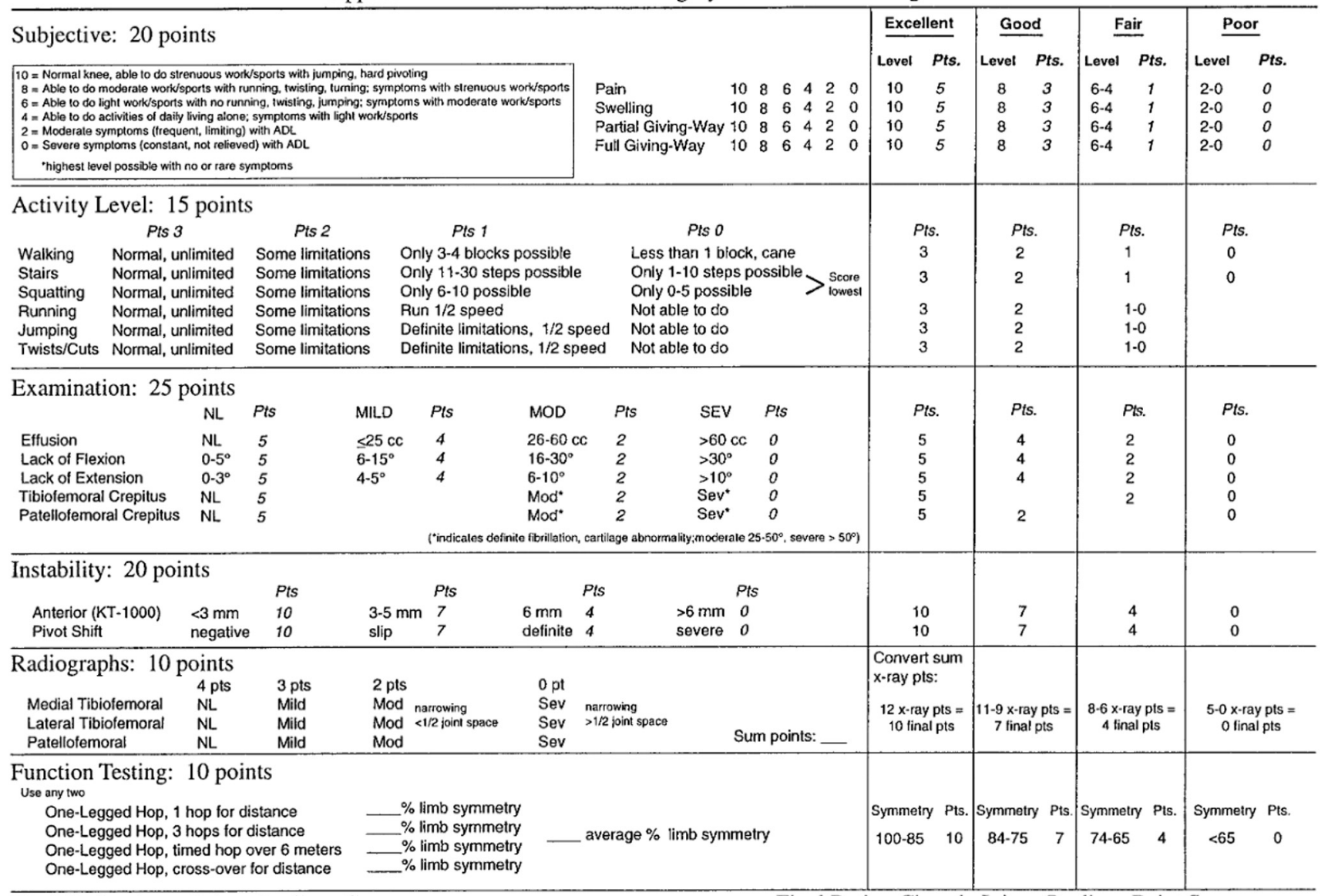

Final Rating Acute Injury Studies: Category

Final Rating Chronic Injury Studies: Point Sum

Excellent: all in "excellent" (may have one in "good"); Good: all in "excellent" and "good"

Fair: any one in "fair"; Poor: any one in "poor" 
Appendix V. Modifications for Overall Rating Scheme: Symptom and Instability Ratings

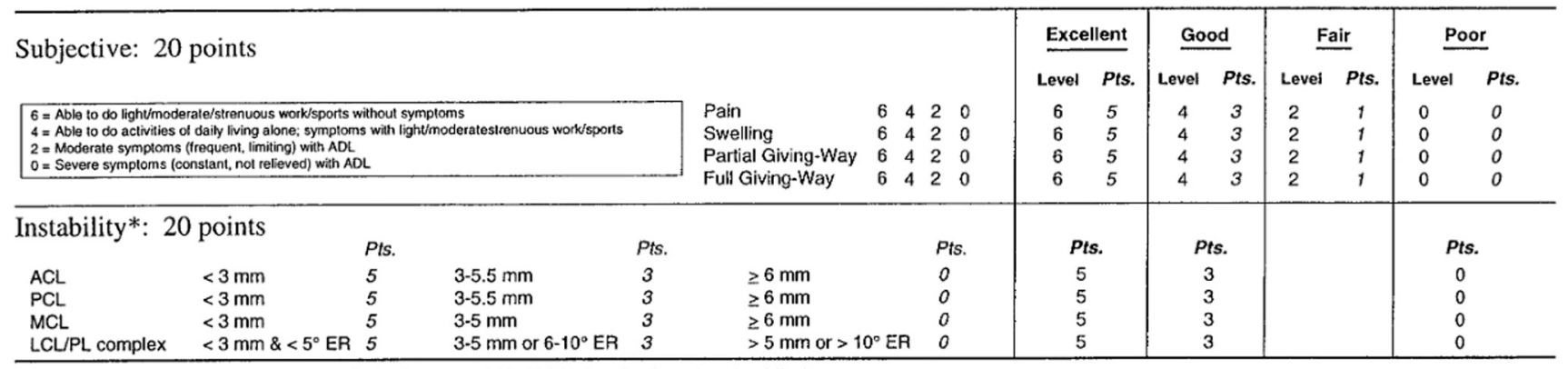

*ACL: use knee arthrometer test total AP displacement $20^{\circ}, 134 \mathrm{~N}$, involved-noninvolved limb

PCL: use knce arthrometer test $\left(70^{\circ}, 89 \mathrm{~N}\right)$ or stress radiographs $\left(70^{\circ}, 89 \mathrm{~N}\right)$

MCL: use valgus stress test, 25

LCL/PL complex: use varus stress test $25^{\circ}$, external tibial rotation test $30^{\circ} \& 90^{\circ}$, varus recurvatum test 


\begin{tabular}{|c|c|c|c|c|c|c|c|c|c|}
\hline Domain & Question Stem & Question & IKDC & KOOS & Lysholm & Tegner & Marx & KOS & Cincinnati \\
\hline \multirow[t]{4}{*}{$\begin{array}{l}\text { Pain } \\
\end{array}$} & Pain frequency & $\begin{array}{l}\text { During the past } 4 \text { weeks, or since your injury, how often have } \\
\text { you had pain? }\end{array}$ & + & & & & & & \\
\hline & & How often do you experience knee pain? & & + & & & & & \\
\hline & Pain severity & If you have pain, how severe is it? & + & & & & & & \\
\hline & & Pain & & & + & & & + & + \\
\hline \multirow[t]{14}{*}{ Symptom } & Stiffness/Swelling & $\begin{array}{l}\text { During the past } 4 \text { weeks, or since your injury, how stiff or } \\
\text { swollen was your knee? }\end{array}$ & + & & & & & & \\
\hline & & $\begin{array}{l}\text { How severe is your knee joint stiffness after first wakening in the } \\
\text { morning? }\end{array}$ & & + & & & & & \\
\hline & & $\begin{array}{l}\text { How severe is your knee stiffness after sitting, lying or resting } \\
\text { later in the day? }\end{array}$ & & + & & & & & \\
\hline & & $\begin{array}{l}\text { Swelling (in your knee)? } \\
\text { Stiffness }\end{array}$ & & + & + & & & $\begin{array}{l}+ \\
+\end{array}$ & + \\
\hline & Lock/Catch & $\begin{array}{l}\text { During the past } 4 \text { weeks, or since your injury, did your knee lock } \\
\text { or catch? }\end{array}$ & + & & & & & & \\
\hline & & Does your knee catch or hang up when moving? & & + & & & & & \\
\hline & & Locking & & & + & & & & \\
\hline & Giving way & $\begin{array}{l}\text { What is the highest level of activity you can perform without } \\
\text { significant giving way in your knee? }\end{array}$ & + & & & & & & \\
\hline & & Instability ("Giving way sensation from the knee") & & & + & & & & \\
\hline & & Giving way, buckling, or shifting of the knee & & & & & & + & \\
\hline & & (Slipping or) Partial giving way & & & & & & + & + \\
\hline & & (Buckling or) Full giving way & & & & & & + & + \\
\hline & $\begin{array}{l}\text { Knee sensations } \\
\text { (e.g., grinding) }\end{array}$ & $\begin{array}{l}\text { Do you feel grinding or hear clicking or any other type of noise } \\
\text { when your knee moves? }\end{array}$ & & + & & & & & \\
\hline & & Grinding or grating & & & & & & + & \\
\hline \multirow{18}{*}{$\begin{array}{l}\text { Functional } \\
\text { Activities }\end{array}$} & Stairs & Go upstairs (ascending) & + & + & & & & + & \\
\hline & & Go down stairs (descending) & + & + & & & & + & \\
\hline & & Stairs & & & + & & & & + \\
\hline & Kneeling & Kneel on the front of your knee & + & & & & & + & \\
\hline & & Squatting / kneeling & & & & & & & + \\
\hline & Squatting & Squatting & + & & + & & & + & \\
\hline & & Squatting / kneeling & & & & & & & + \\
\hline & Sitting & Sit with your knee bent & + & & & & & + & \\
\hline & & Sitting & & + & & & & & \\
\hline & Rising & Rise from a chair & + & & & & & + & \\
\hline & & Rising from sitting & & + & & & & & \\
\hline & Function/condition & Current function on your knee & + & & & & & & \\
\hline & & Rate the overall condition of your knee at the present time & & & & & & & + \\
\hline & Walking & Walking on flat surface & & + & & & & & \\
\hline & & Walking on even ground & & & & + & & & \\
\hline & & Walking & & & & & & + & + \\
\hline & $\begin{array}{l}\text { Heavy domestic } \\
\text { duties }\end{array}$ & $\begin{array}{l}\text { Heavy domestic duties (moving heavy boxes, scrubbing floors, } \\
\text { etc.) }\end{array}$ & & + & & & & & \\
\hline & & $\begin{array}{l}\text { Work (Moderately heavy labor [e.g., truck driving, heavy } \\
\text { domestic work]) }\end{array}$ & & & & + & & & \\
\hline
\end{tabular}




\begin{tabular}{|c|c|c|c|c|c|c|c|c|c|}
\hline Domain & Question Stem & Question & $\mathrm{IKDC}$ & KOOS & Lysholm & Tegner & Marx & KOS & Cincinnat \\
\hline \multirow[t]{19}{*}{$\begin{array}{l}\text { Sports/ } \\
\text { Recreation }\end{array}$} & $\begin{array}{l}\text { Highest level of } \\
\text { activity }\end{array}$ & $\begin{array}{l}\text { What is the highest level of activity you can participate in on a } \\
\text { regular basis? }\end{array}$ & + & & & & & & \\
\hline & & Sports Activity Scale & & & & & & & + \\
\hline & $\begin{array}{l}\text { Walking uneven } \\
\text { surface }\end{array}$ & $\begin{array}{l}\text { Walking on uneven ground possible but impossible to walk in } \\
\text { forest }\end{array}$ & & & & + & & & \\
\hline & & Walking on uneven ground & & & & & & & + \\
\hline & Running & Run straight ahead / Straight running & + & & & & & + & + \\
\hline & & Running & & + & & & & & \\
\hline & & Running: running while playing a sport or jogging & & & & & + & & \\
\hline & Jumping & $\begin{array}{l}\text { Jump and land on your involved/affected leg } \\
\text { Jumping }\end{array}$ & + & + & & & & + & + \\
\hline & & $\begin{array}{l}\text { Bandy; Squash or badminton; Athletics (jumping, etc.); Downhill } \\
\text { skiing }\end{array}$ & & & & + & & & \\
\hline & & $\begin{array}{l}\text { Competitive sports (tennis; athletics [running]; motocross, } \\
\text { speedway; handball; basketball) or recreational sports (soccer, } \\
\text { bandy, and ice hockey; squash, athletics [jumping], cross- } \\
\text { country track, findings both recreational and competitive) }\end{array}$ & & & & + & & & \\
\hline & Stopping/Starting & Stop and start quickly & + & & & & & + & \\
\hline & & Deceleration: coming to a quick stop while running & & & & & + & & \\
\hline & Pivoting & Twisting/pivoting on your injured knee & & + & & & & & \\
\hline & & $\begin{array}{l}\text { Pivoting: turning your body with your foot planted while playing } \\
\text { sport, e.g., skiing, skating, kicking, throwing, hitting a ball } \\
\text { (golf, tennis, squash). }\end{array}$ & & & & & + & & \\
\hline & & Cut and pivot on your involved leg & & & & & & + & \\
\hline & & Hard twists / cuts / pivots & & & & & & & + \\
\hline & Cutting & Cutting: changing directions while running & & & & & + & & \\
\hline & & Cut and pivot on your involved leg & & & & & & + & \\
\hline & & Hard twists / cuts / pivots & & & & & & & + \\
\hline
\end{tabular}

Note that questions listed may also appear in Table 2 (Identical Questions) because two questions are identical, but a question from another survey is similar to the two identical questions. As a result, two of the questions would be identical and the third would be similar. 